\title{
Analisis Kesalahan Siswa Berdasarkan Objek Matematika Menurut Soedjadi pada Materi Determinan dan Invers Matriks
}

\author{
Restu Ayu Gustianingrum ${ }^{1 *}$, Kartini ${ }^{2}$ \\ 1*,2Program Studi Magister Pendidikan Matematika, Universitas Riau \\ Kampus Bina Widya KM 12.5, Simpang Baru, Tampan, Pekanbaru, Riau, Indonesia \\ 1*restuayu219@gmail.com; ${ }^{2}$ kartini@lecturer.unri.ac.id
}

Artikel diterima: 23-01-2021, direvisi: 10-05-2021, diterbitkan: 31-05-2021

\begin{abstract}
Abstrak
Sebagian besar siswa terkadang membuat kesalahan dalam menyelesaikan soal-soal matematika baik yang disengaja maupun tidak disengaja. Penelitian ini bertujuan untuk menganalisis kesalahan-kesalahan yang dilakukan siswa dalam mengerjakan soal pada materi determinan dan invers matriks. Jenis penelitian ini adalah penelitian kualitatif. Teknik pengumpulan data yang digunakan adalah teknik tes dan wawancara secara daring. Subjek penelitian yaitu 30 siswa XI MIA 1 MAN 3 Kota Pekanbaru tahun pelajaran 2020/2021. Analisis kesalahan siswa dilihat berdasarkan objek matematika menurut Soedjadi yaitu fakta, konsep, prinsip, dan operasi. Hasil analisis kesalahan menunjukkan bahwa kesalahan paling banyak dilakukan siswa adalah kesalahan konsep dengan persentase sebesar $17,3 \%$. Penyebab terjadinya kesalahan yang dilakukan siswa adalah siswa belum memahami konsep matriks, siswa lupa dengan konsep matriks dan kurang teliti dalam melakukan operasi perhitungan. Dalam pembelajaran, hendaknya guru tidak mengajarkan siswa untuk menghafalkan rumus namun lebih mengutamakan pemahaman konsep siswa.

Kata Kunci: analisis, determinan dan invers matriks, kesalahan siswa.
\end{abstract}

\section{Analysis of Student Errors Based on Mathematical Objects According to Soedjadi on the Determinants and Inverse Matrices}

\begin{abstract}
Most students sometimes make mistakes in solving math problems, either deliberately or unintentionally. This study aims to analyze the errors made by students in working on the questions on the determinant and inverse matrix material. This type of research is qualitative research. The data collection techniques used were online test and interview techniques. The research subjects were 30 students of XI MIA 1 MAN 3 Pekanbaru City in the 2020/2021 school year. Analysis of student errors is seen based on mathematical objects according to Soedjadi, namely facts, concepts, principles, and operations. The results of the error analysis showed that the most mistakes made by students were misconceptions with a percentage of $17.3 \%$. The cause of the errors made by students is that students do not understand the concept of the matrix, students forget the concept of the matrix, and are not careful in performing calculation operations. In learning, the teacher should not teach students to memorize formulas but prioritize students' understanding of concepts.
\end{abstract}

Keywords: analysis, determinan and inverse matrices, student error. 


\section{Pendahuluan}

Pada era digital saat ini, kemajuan ilmu pengetahuan, teknologi informasi dan komunikasi sangat pesat. Hal tersebut juga dipengaruhi oleh peran matematika sebagai ilmu yang menjadi dasar ilmu-ilmu lainnya (Lucas, dkk., 2017). Namun, matematika masih dianggap pelajaran yang sulit dan tidak menarik, sehingga siswa mengalami kesulitan untuk belajar matematika (Kunwar, 2020). Sebagai alat pikir dan alat pemecahan masalah, kemampuan matematika siswa Indonesia ternyata masih tergolong rendah (Tasya, 2018). Padahal matematika sangat berguna dalam kehidupan sehari-hari dan menunjang bidang ilmu lainnya, sehingga matematika dikatakan sebagai ratu dari segala ilmu. Siswa dituntut untuk teliti dalam menggunakan matematika, baik dalam hal fakta, konsep, prinsip ataupun prosedur (Suciati \& Wahyuni, 2018).

Tujuan pembelajaran matematika mengacu pada Permendikbud No. 58 tahun 2014 (Depdikbud, 2014; Shafira, Suanto, \& Kartini, 2021). Beberapa diantaranya yaitu: (1) memahami konsep matematika sebagai kompetensi dalam menjelaskan keterkaitan antarkonsep dan menggunakan konsep maupun algoritma, secara luwes, akurat, efisien, dan tepat, dalam pemecahan masalah; menggunakan pola sebagai dugaan dalam penyelesaian masalah dan mampu membuat generalisasi berdasarkan fenomena atau data yang ada; (3) menggunakan penalaran pada sifat, melakukan manipulasi matematika baik dalam penyederhanaan, maupun menganalisa komponen yang ada dalam pemecahan masalah dalam konteks matematika maupun di luar matematika (kehidupan nyata, ilmu, dan teknologi) yang meliputi kemampuan memahami masalah, membangun model matematika, menyelesaikan model dan menafsirkan solusi yang diperoleh termasuk dalam rangka memecahkan masalah dalam kehidupan sehari-hari (dunia nyata).

Ketercapaian tujuan pembelajaran matematika tersebut dapat dilihat berdasarkan pembelajaran yang terjadi di kelas. Salah satu faktor yang mempengaruhi keberhasilan pembelajaran adalah kemampuan siswa (Sun, Xie, \& Anderman, 2018; Nurkamilah \& Afriansyah, 2021). Jika kemampuan siswa rendah, maka hasil belajar siswa juga akan rendah (Chotimah, Bernard, \& Wulandari, 2018). Oleh karena itu, guru perlu melakukan tes pada suatu bahasan tertentu kepada siswa untuk melihat bagaimana ketercapaian tujuan pembelajaran matematika. Namun, siswa terkadang membuat kesalahan dalam menjawab sehingga akan berdampak pada hasil dari yang dikerjakan (Licorish, Owen, Daniel, \& George, 2018). Hal ini dapat terlihat melalui kesalahan-kesalahan dan ketidakmampuan siswa dalam menyelesaikan soal matematika.

Kesalahan merupakan suatu bentuk penyimpangan terhadap hal yang benar, prosedur yang ditetapkan sebelumnya, atau penyimpangan dari suatu yang diharapkan (Setiawan, Hapizah, \& Hiltrimartin, 2018; Gerhani, 2019). Menurut Cintia (2018) kesalahan merupakan upaya si pembelajar untuk mengikuti kaidah-kaidah yang diyakininya atau diharapkannya, benar atau tepat, tetapi sebenarnya salah dalam beberapa 
hal. Menurut Lusiana (2017) dengan adanya kesalahan-kesalahan yang dilakukan siswa mengakibatkan menurunnya nilai siswa pada mata pelajaran matematika. Sejalan dengan penelitian (Nuraini, 2016) kesalahan dapat menurunkan rasa percaya diri dalam menyelesaikan permasalahan yang mengakibatkan penurunan kemampuan siswa.

Kesalahan matematika dapat ditinjau berdasarkan objek matematika menurut Soedjadi (Cahyani \& Sutriyono, 2018) yang terdiri dari empat objek matematika, yaitu fakta, konsep, prinsip dan operasi. Berdasarkan hasil penelitian yang telah dilakukan oleh Fausan (2019) siswa melakukan kesalahan dikarenakan kurangnya pemahaman konsep, kurang cermat dalam melakukan perhitungan dan kurang teliti dalam menuliskan simbol. Sejalan dengan penelitian Aly (2019) beberapa kesalahan yang dilakukan siswa dalam menyelesaikan soal matematika yaitu kesalahan konsep, prosedur dan operasi, dimana persentase kesalahan paling tinggi yang dilakukan siswa adalah kesalahan operasi yakni sebesar 58,43\%.

Setiap siswa di kelas XI MAN 3 Kota Pekanbaru harus memiliki kemampuan pemahaman konsep yang tinggi dan cermat dalam melakukan perhitungan. Kelas XI MIA 1 MAN 3 Kota Pekanbaru termasuk kelas unggul di antara kelas lainnya. Namun, berdasarkan data nilai penilaian harian 30 orang siswa kelas XI MIA 1 MAN 3 Kota Pekanbaru pada materi operasi matriks, didapatkan bahwa beberapa nilai siswa mengalami penurunan.
Penelitian ini menganalisis kesalahan siswa dalam menyelesaikan soal pada materi determinan dan invers matriks yang ditinjau berdasarkan kesalahan siswa dari segi objek matematika. Ini yang menjadi perbedaan dengan penelitianpenelitian sebelumnya. Ada beberapa penyebab yang diduga sebagai pemicu kesalahan siswa pada materi operasi matriks. Diantaranya adalah pemahaman konsep siswa yang masih kurang, lebih menekankan kepada hafalan, serta dikarenakan proses pembelajaran yang berlangsung secara daring yang membuat siswa kesulitan dalam melaksanakan proses pembelajaran mandiri (Harisuddin, 2021; Prasetyo \& Zulela, 2021).

Dalam pembelajaran matematika, materi matriks termasuk materi yang tidak terlalu sulit, namun tetap harus dipahami dengan teliti (Ramziah, 2016). Salah satu sub-materi matriks dimana siswa banyak melakukan kesalahan adalah determinan dan invers matriks. Pada materi determinan dan invers matriks dibutuhkan pemahaman fakta, konsep, prinsip, dan operasi yang baik.

Temuan dalam penelitian ini yaitu siswa paling banyak melakukan kesalahan konsep dalam menyelesaikan soal determinan dan invers matriks. Hal ini diharapkan bisa menjadi masukan bagi guru sebagai pemegang utama dalam pembelajaran agar lebih memperhatikan kemasan pembelajaran yang tidak menekankan siswa pada segi hafalan rumus saja, tetapi bagaimana agar siswa memiliki kemampuan memahami suatu konsep matematika, sehingga ketika menyelesaikan soal siswa bisa mencari 
solusinya dengan menggunakan konsep matematika yang benar.

Berdasarkan uraian di atas peneliti terdorong untuk menganalisis kesalahan matematika siswa ditinjau dari tingkat kemampuan matematika siswa pada materi determinan dan invers matriks dan mengidentifikasi penyebab terjadinya kesalahan-kesalahan tersebut.

Adapun tujuan yang ingin peneliti capai dalam artikel ilmiah ini adalah menganalisis jenis kesalahan dan mengetahui penyebab kesalahan yang dilakukan siswa dalam menyelesaikan soalsoal determinan dan invers matriks.

\section{Metode}

Jenis penelitian ini merupakan penelitian eksploratif dengan pendekatan deskriptif kualitatif dan deskriptif kuantitatif (Indraswari \& Fitriyah, 2019). Jenis kesalahan dikategorikan berdasarkan objek matematika menurut Soedjadi yaitu kesalahan fakta, konsep, prinsip dan operasi (Muda, Alhaddad, \& Saidi, 2021). Proses kegiatan analisis data pada penelitian ini dilakukan dengan langkahlangkah sebagai berikut: (1) hasil pekerjaan siswa dikoreksi, (2) skor yang diperoleh siswa dihitung pada tiap butir soal, (3) jenis kesalahan dideskripsikan pada tiap butir soal, (4) persentase banyak siswa dihitung pada tiap jenis kesalahan, dan (5) siswa yang melakukan kesalahan diwawancara untuk mengetahui penyebab kesalahan.

Teknik pengumpulan data pada penelitian ini adalah teknik tes dan wawancara. Instrumen tes yang digunakan adalah lima soal uraian yang berkaitan dengan materi determinan dan invers matriks dan disesuaikan dengan kebutuhan

penelitian. Soal tes diuji untuk mengetahui validitas dan reliabilitas menggunakan anates. Berdasarkan hasil uji coba instrumen tes, indeks korelasinya sebesar 0,96 . Ini menunjukkan bahwa soal tes yang dibuat memiliki validitas yang sangat tinggi, begitu pula dengan reliabilitasnya yang bernilai 0,98 termasuk kategori sangat tinggi. Data hasil tes diolah dan dianalisis dengan mengacu pada pedoman penskoran. Adapun soal tes yang digunakan sebagai berikut.

\section{Soal 1}

Indikator pencapaian kompetensi yang diharapkan adalah menentukan determinan dan invers matriks ordo $2 \times 2$ (perhatikan Gambar 1). Pada bagian 1(a), siswa diminta untuk menentukan determinan matriks $A$ sedangkan bagian 1(b) siswa diminta untuk menentukan invers matriks $A$.

1. Diketahui matriks $A=\left[\begin{array}{cc}2 & -3 \\ 5 & -7\end{array}\right]$ tentukanlah:

a. Determinanmatriks A

b. Invers matriks A

Gambar 1. Soal 1.

\section{Soal 2}

Indikator pencapaian kompetensi yang diharapkan adalah menelaah sifat-sifat determinan matriks (perhatikan Gambar 2). Siswa diminta untuk menunjukkan kebenaran dari kesamaan dua buah matriks yang disesuaikan dengan salah satu sifat determinan matriks.

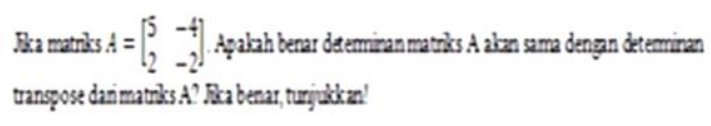

Gambar 2. Soal 2. 
Soal 3

Indikator pencapaian kompetensi yang diharapkan adalah menggunakan determinan dan invers matriks untuk menyelesaikan masalah yang berkaitan dengan matriks ordo $2 \times 2$ (perhatikan Gambar 3). Siswa diminta untuk menentukan nilai $k^{2}+k-1$ dari $k \operatorname{det} P^{-1}=\operatorname{det}(P Q)^{T}$.

3. Diketahui matriks $P=\left[\begin{array}{ll}3 & 1 \\ 5 & 2\end{array}\right], Q=\left[\begin{array}{cc}-2 & -3 \\ 3 & 4\end{array}\right]$.

Jika $k \operatorname{det} P^{-1}=\operatorname{det}(P Q)^{T}$, tentukanlah nilai $k^{2}+k-1$ !

Gambar 3. Soal 3

Soal 4

Indikator pencapaian kompetensi yang diharapkan adalah menentukan determinan dan invers matriks ordo $3 \times 3$ (perhatikan Gambar 4). Pada bagian 4(a) siswa diminta untuk menentukan determinan matriks A dengan menggunakan aturan sarrus. Pada bagian 4(b) siswa diminta untuk menentukan invers matriks $A$.

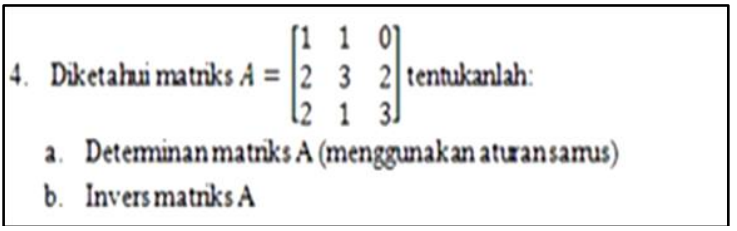
Gambar 4. Soal 4.

\section{Soal 5}

Indikator pencapaian kompetensi yang diharapkan adalah menggunakan invers matriks ordo $3 \times 3$ untuk menyelesaikan masalah kontekstual sistem persamaan linear tiga variabel (perhatikan Gambar 5). Pada bagian 5(a) siswa diminta untuk menuliskan apa yang diketahui dan ditanya dari permasalahan yang diberikan. Pada bagian 5(b) siswa diminta untuk membuat model matematika dari permasalahan yang diberikan. Pada bagian 5(c) siswa diminta untuk menuliskan model matematika dalam bentuk matriks. Pada bagian 5(d) siswa diminta untuk menyelesaikan permasalahan dengan menggunakan invers matriks.

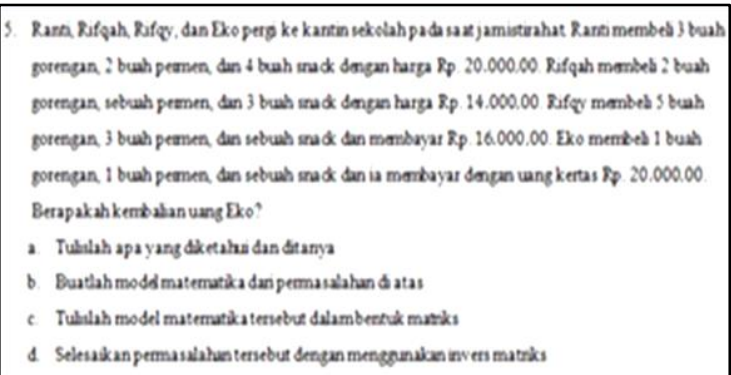
Gambar 5. Soal 5.

Subjek pada penelitian ini adalah 30 siswa kelas XI MIA 1 MAN 3 Kota Pekanbaru semester ganjil 2020/2021. Objek dalam penelitian ini adalah analisis kesalahan siswa dalam menyelesaikan soal uraian pada materi determinan dan invers matriks.

Setelah peneliti mengolah data dengan mengecek kesalahan-kesalahan yang dilakukan siswa, peneliti melakukan wawancara kepada siswa yang melakukan kesalahan untuk mengetahui penyebab terjadinya kesalahan.

\section{Hasil dan Pembahasan}

Hasil analisis kesalahan siswa pada tiap jenis kesalahan dapat dilihat pada Tabel 1.

Tabel 1.

Persentase Kesalahan Siswa

\begin{tabular}{|ccccccc|}
\hline \multirow{2}{*}{$\begin{array}{c}\text { Jenis } \\
\text { Kesalaha } \\
\mathrm{n}\end{array}$} & \multicolumn{4}{c}{$\begin{array}{c}\text { Persentase Banyak Siswa yang } \\
\text { Melakukan Kesalahan pada Tiap } \\
\text { Soal (\%) }\end{array}$} & $\begin{array}{c}\text { Rata- } \\
\text { Rata }\end{array}$ \\
\cline { 2 - 6 } & $\mathbf{1}$ & $\mathbf{2}$ & 3 & $\mathbf{3}$ & $\mathbf{5}$ & \\
\hline Fakta & 0 & 3,3 & 3,3 & 6,7 & 3,3 & $3,3 \%$ \\
\hline Konsep & 36,7 & 3,3 & 10 & 6,7 & 30 & $17,3 \%$ \\
\hline Prinsip & 0 & 0 & 16,7 & 13,3 & 10 & $8 \%$ \\
\hline
\end{tabular}


$\begin{array}{lllllll}\text { Operasi } & 0 & 10 & 6,7 & 43,3 & 3,3 & 12,7 \%\end{array}$

Pada jenis kesalahan fakta (lihat Tabel 1) hanya sedikit siswa yang melakukan kesalahan yaitu sebesar 3,3\%. Pada jenis kesalahan konsep, persentase siswa yang melakukan kesalahan sebesar 17,3\%. Kesalahan konsep merupakan jenis kesalahan paling banyak dilakukan siswa. Pada jenis kesalahan prinsip, siswa yang melakukan kesalahan lebih sedikit dibanding kesalahan konsep yaitu sebesar 8\%. Pada jenis kesalahan operasi, siswa yang melakukan kesalahan lebih banyak dibanding kesalahan fakta dan kesalahan prinsip yaitu sebesar $12,7 \%$.

Berikut merupakan pemaparan contoh kesalahan-kesalahan yang dilakukan oleh siswa.

\section{Kesalahan Fakta}

Salah satu contoh kesalahan fakta yang dilakukan siswa terdapat pada soal 3 (lihat Gambar 6). Siswa melakukan kesalahan dalam menuliskan simbol " $=$ " pada operasi perkalian matriks ordo $2 \times 2$. Seharusnya siswa menuliskan simbol perkalian. Berdasarkan hasil wawancara, dapat diketahui bahwa siswa kurang teliti dalam menuliskan simbol-simbol matematika seperti simbol perkalian.

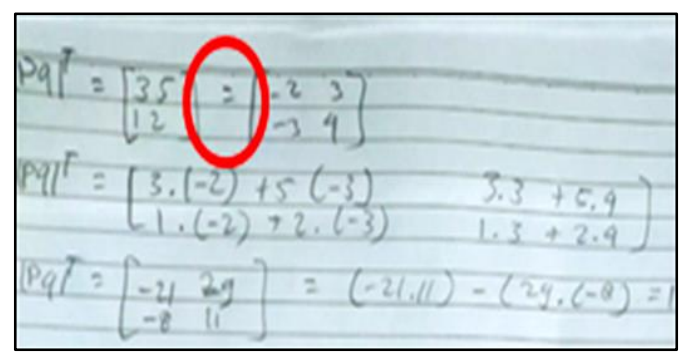

Gambar 6. Contoh Jawaban Siswa pada Soal 3.

\section{Kesalahan Konsep}

Salah satu contoh kesalahan konsep yang dilakukan siswa terdapat pada soal 1 (lihat gambar 7), kesalahan yang dilakukan siswa adalah kesalahan konsep invers. Siswa tidak merubah tanda -3 dan -5 . Berdasarkan wawancara, siswa menyatakan bahwa ia lupa dengan konsep determinan matriks ordo $2 \times 2$.

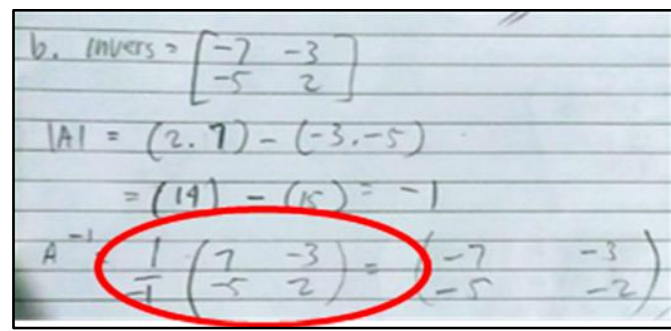

Gambar 7. Contoh Jawaban Siswa pada Soal 1.

Kesalahan konsep juga dilakukan siswa pada soal 5 (lihat Gambar 8). Kesalahan yang dilakukan siswa adalah kesalahan konsep invers. Siswa menyelesaikan masalah menggunakan konsep determinan matriks, sedangkan berdasarkan perintah soal yang diminta adalah mengunakan konsep invers matriks. Berdasarkan wawancara, diketahui bahwa siswa kurang memahami konsep dan tidak teliti dalam membaca perintah soal.

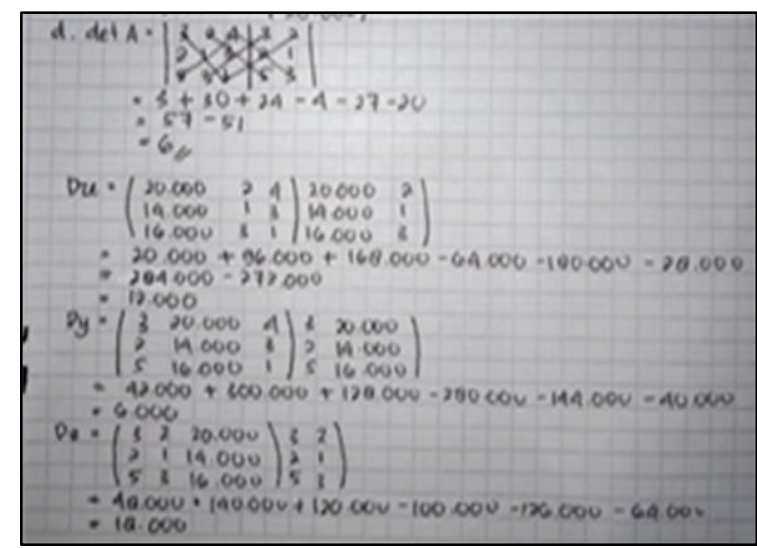

Gambar 8. Contoh Jawaban Siswa pada Soal 5.

\section{Kesalahan Prinsip}

Salah satu contoh kesalahan prinsip yang dilakukan siswa terdapat pada soal 4 (lihat Gambar 9). Kesalahan yang dilakukan siswa adalah kesalahan prinsip invers. Siswa salah dalam menggunakan rumus invers matriks ordo $3 \times 3$. Berdasarkan hasil 
wawancara, diketahui bahwa siswa belum mengerti dengan rumus invers matriks, terutama pada bagian adjoin matriks.

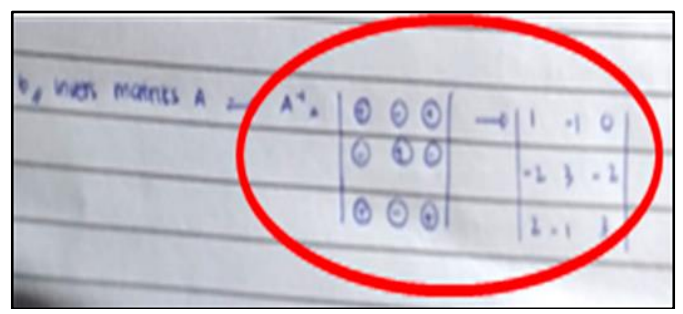

Gambar 9. Contoh Jawaban Siswa pada Soal 4.

\section{Kesalahan Operasi}

Salah satu contoh kesalahan operasi yang dilakukan siswa terdapat pada soal 2 (lihat Gambar 10), kesalahan yang dilakukan siswa adalah kesalahan operasi penjumlahan, sehingga hasil akhir pun menjadi salah. Berdasarkan hasil wawancara, dapat diketahui bahwa siswa melakukan kesalahan operasi perhitungan karena teburu-buru ingin menyelesaiakn soal dan ingin cepat selesai. Siswa juga kurang teliti dalam melakukan operasi perhitungan yang menyebabkan hasil akhir menjadi salah.

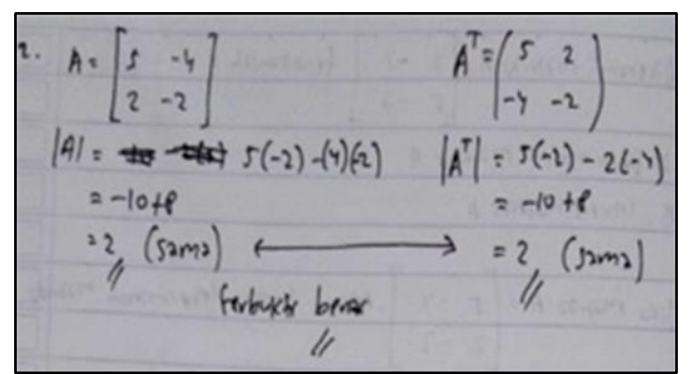

Gambar 10. Contoh Jawaban Siswa pada Soal 2.

Berdasarkan penelitian terdahulu yang dilakukan oleh Ainin (2020) dan Tamba (2020) tentang analisis kesalahan siswa dalam menyelesaikan soal matriks, ditemukan beberapa jenis kesalahan seperti kesalahan operasi, konsep, dan prinsip. Kesalahan tersebut berkaitan dengan anggapan siswa bahwa matematika merupakan pelajaran yang sulit dan tidak menarik. Selain itu, Nuritasari (2017) dan Hasyim \& Andreina (2019) yang menyatakan bahwa kesalahan yang dilakukan siswa dalam menyelesaikan soal matematika pada pokok bahasan matriks yaitu kesalahan memahami soal, kesalahan menyelesaikan soal dan kesalahan menuliskan jawaban akhir. Faktor penyebab kesalahan yang dilakukan siswa adalah kurang teliti dalam melakukan operasi hitung yang menyebabkan kesalahan pada jawaban akhir. Hal itu disebabkan masih banyak siswa yang belum memahami konsep matriks dan tidak cermat dalam perhitungan dan kurangnya minat siswa dalam belajar matematika karena matematika dianggap sebagai pelajaran yang sulit dan tidak menarik. Sejalan dengan penelitian Wulanndari (2016), jenis kesalahan yang dilakukan siswa dalam menyelesaikan soal materi matriks adalah kesalahan konsep, prinsip dan keterampilan. Jenis kesalahan terbesar yang dilakukan siswa adalah kesalahan konsep dengan persentase $28,75 \%$. Hal itu disebabkan karena siswa kebingungan dalam menyelesaikan soal dan lupa konsep.

Berdasarkan beberapa temuan dalam penelitian terkait analisis kesalahan siswa pada materi determinan dan invers matriks, dapat disimpulkan bahwa siswa melakukan kesalahan berupa kesalahan fakta, konsep, prinsip, dan operasi. Kesalahan yang paling banyak dilakukan adalah kesalahan konsep dengan persentase 17,3\%. Berdasarkan hasil wawancara dengan siswa ditemukan bahwa siswa kurang memahami konsep dan kurang teliti dalam mengerjakan soal 
karena terburu-buru ingin cepat selesai. Hal ini sejalan dengan penelitian Krismantono (2018) dan Wahyuningsih (2020) yang mengatakan bahwa penyebab terjadinya kesalahan yang dilakukan siswa adalah siswa belum memahami konsep matriks, lupa dengan konsep matriks dan kurang teliti dalam melakukan operasi perhitungan.

Oleh karena itu, peneliti memberikan solusi dalam melaksanakan pembelajaran yang dapat dipertimbangkan oleh guru dan siswa. Guru sebaiknya menanamkan konsep determinan dan invers matriks kepada siswa, tidak hanya mengajarkan siswa menghafal rumus. Guru dapat menggunakan model-model pembelajaran yang dapat meningkatkan pemahaman konsep agar siswa tidak melakukan kesalahan-kesalahan dalam mengerjakan soal determinan dan invers matriks. Siswa harus lebih teliti dalam membaca dan memahami permasalahan yang diberikan agar kesalahan tidak terulang kembali.

\section{Penutup}

Kesalahan-kesalahan yang dilakukan siswa dalam menyelesaikan soal-soal determinan dan invers matriks diantaranya kesalahan fakta, konsep, prinsip dan operasi. Jenis kesalahan paling banyak dilakukan adalah kesalahan konsep sebesar 17,3\%. Hal itu disebabkan oleh masih banyak siswa yang belum memahami konsep matriks. Siswa juga tidak cermat dalam melakukan perhitungan.

Dalam pembelajaran, hendaknya guru tidak mengajarkan siswa untuk menghafalkan rumus namun lebih mengutamakan pemahaman konsep. Selain itu, siswa harus lebih cermat dalam melakukan perhitungan karena jika salah sedikit saja maka hasil akhirnya akan menjadi salah.

\section{Daftar Pustaka}

Ainin, N. (2020). Analisis Kesalahan Siswa dalam Menyelesaikan Soal Matriks dan Kaitannya dengan Motivasi Belajar Matematika pada Kelas XI. Euclid, 7(2), 137-147.

Aly, B. F. N., Sujadi, A. A., \& Taufiq, I. (2019). Analisis Kesalahan dalam Menyelesaikan Soal Matematika pada Siswa Kelas X SMK Negeri 1 Seyegan. Union Jurnal Ilmiah Pendidikan Matematika, 7(1), 135-144.

Cahyani, C. A., \& Sutriyono. (2018). Analisis Kesalahan Siswa dalam Menyelesaikan Soal pada Materi Operasi Penjumlahan dan Pengurangan Bentuk Aljabar bagi Siswa Kelas VII SMP Kristen 2 Salatiga. Jurnal Teori dan Aplikasi Matematika, 2(1), 26-30.

Chotimah, S., Bernard, M., \& Wulandari, S. M. (2018). Contextual approach using VBA learning media to improve students' mathematical displacement and disposition ability. In Journal of Physics: Conference Series (Vol. 948, No. 1, p. 012025). IOP Publishing.

Cintia, N. I., Kristin, F., \& Anugraheni, I. (2018). Penerapan Model Pembelajaran Discovery Learning Untuk Meningkatkan Kemampuan Berpikir Kreatif dan Hasil Belajar Siswa. Perspektif IImu Pendidikan, 32(1),6775.

Fausan, Sugita, G., \& Sukayasa. (2019). Profil Kesalahan Siswa dalam Menyelesaikan Soal Matriks Berdasarkan Jenis Kelamin di SMA Negeri 7 Palu. Aksioma, 8(2), 110-124. 
Depdikbud. (2014). Permendikbud No. 58 Tahun 2014 tentang Kurikulum SMP. Jakarta: BNSP

Gerhani, J., Bey, A., \& La Ndia. (2019). Analisis Kesalahan Matematika Materi lingkaran Ditinjau dari Tingkat Kemampuan Matematika Siswa Kelas VIII SMP Negeri 12 Kendari. Jurnal Penelitian Pendidikan Matematika, 7(2), 99-112.

Harisuddin, M. I. (2021). Kemampuan Pemecahan Masalah Matematis dan Kemandirian Belajar Siswa dengan PJJ di masa Covid-19. Teorema: Teori dan Riset Matematika, 6(1), 98-106.

Hasyim, M., \& Andreina, F. K. (2019). Analisis high order thinking skill (hots) siswa dalam menyelesaikan soal open ended matematika. FIBONACCI: Jurnal Pendidikan Matematika Dan Matematika, 5(1), 55-64.

Indraswari, N. F., \& Fitriyah, L. M. (2019). Penalaran Aljabar Mahasiswa dalam Menyelesaikan Masalah Relasi Rekursif Ditinjau dari Gaya Kognitif. SIGMA, 4(2), 38-44.

Krismantono, R. R., \& Purnami, A. S., (2018). Analisis Kesalahan dalam Menyelesaikan Soal Matematika.

Prosiding Seminar Nasional Pendidikan Matematika Enomatnesia.

Kunwar, R. (2020). Math mania: meaning, problems and ways of effective teaching and learning mathematics at basic level education in Nepal. International Journal of Science and Research (IJSR). (9), 8, 1136-1141.

Licorish, S. A., Owen, H. E., Daniel, B., \& George, J. L. (2018). Students' perception of Kahoot!'s influence on teaching and learning. Research and Practice in Technology Enhanced Learning, 13(1), 1-23.

Lucas, R. I., Promentilla, M. A., Ubando, A., Tan, R. G., Aviso, K., \& Yu, K. D. (2017). An AHP-based evaluation method for teacher training workshop on information and communication technology. Evaluation and program planning, 63, 93-100.

Lusiana, R. (2017). Analisis Kesalahan Mahasiswa dalam Memecahkan Masalah pada Materi Himpunan ditinjau dari Gaya Kognitif. Jurnal Penelitian dan Pembelajaran Matematika, 10(1), 24-29.

Muda, H. H., Alhaddad, I., \& Saidi, S. (2021). Analisis Kesalahan Siswa dalam Menyelesaikan Soal Operasi Hitung Bentuk Aljabar. Jurnal Pendidikan Guru Matematika, 1(2).

Nuraini, N. L. S., Suhartono., \& Yuniawatika. (2016). Kesalahan Siswa pada Operasi Penjumlahan dan Pengurangan Pecahan di Kelas VI Sekolah Dasar. Sekolah Dasar: Kajian Teori dan Praktik Pendidikan, 25(2), 168-175.

Nuritasari, F., Hasanah, S. I., \& Sholehoddin, A. (2017). Analisis Kesalahan Siswa dalam Menyelesaikan Soal Matematika Pokok Bahasan Matriks di Kelas XI MA. Jurnal Pendidikan dan Pembelajaran Matematika, 3(2), 108-117.

Nurkamilah, P., \& Afriansyah, E. A. (2021). Analisis Miskonsepsi Siswa pada Bilangan Berpangkat. Mosharafa: Jurnal Pendidikan Matematika, 10(1), 49-60. 
Prasetyo, T., \& Zulela, M. S. (2021). Proses Pembelajaran Daring Guru Menggunakan Aplikasi Whatsapp Selama Pandemik Covid-19. Jurnal Elementaria Edukasia, 4(1).

Ramziah, S. (2016). Peningkatan

Kemampuan Representasi Matematis Siswa Kelas X2 SMAN 1 Gedung Meneng Menggunakan Bahan Ajar Matriks Berbasis Pendekatan Saintifik. Mosharafa: Jurnal Pendidikan Matematika, 5(2), 138-147.

Setiawan, Y. B., Hapizah, H., \& Hiltrimartin, C. (2018). Kesalahan siswa dalam menyelesaikan soal olimpiade SMP konten aljabar. Jurnal Riset Pendidikan Matematika, 5(2), 233-243.

Shafira, R., Suanto, E., \& Kartini, K. (2021). Pengembangan Perangkat Pembelajaran Matematika Dengan Pendekatan Contextual Teaching and Learning Berorientasi Kemampuan Komunikasi Matematis Siswa SMP Kelas VIII. Jurnal Cendekia: Jurnal Pendidikan Matematika, 5(1), 401-410.

Suciati, I., \& Wahyuni, D. S. (2018). Analisis Kesalahan Siswa dalam Menyelesaikan Soal Matematika pada Operasi Hitung Pecahan pada Siswa Kelas V SDN Pengawu. Jurnal Penelitian dan Pembelajaran Matematika, 11(2), 129144.

Sun, Z., Xie, K., \& Anderman, L. H. (2018). The role of self-regulated learning in students' success in flipped undergraduate math courses. The Internet and Higher Education, 36, 4153.

Tamba, K. P. (2020). Analisis Kesalahan Pada Materi Kuantifikasi Menggunakan Matriks Enam Sel. JUMLAHKU: Jurnal
Matematika

IImiah

STKIP

Muhammadiyah Kuningan, 6(2), 102115.

Tasya, R. N. N., Rahayu, E. S., \& Hidayat, W. (2018). Analisis Kesalahan Operasi Hitung Siswa SMK pada Materi Matriks dengan Pedekatan Pembelajaran Problem Based Learning. Jurnal Pendidikan Tambusai, 2(3), 18511853.

Wahyuningsih, D. (2020). Analisis Kesalahan Siswa dalam Menyelesaikan Soal pada Materi Operasi Matriks di SMA YABT Manokwari. Jurnal Perspektif Pendidikan, 14(2), 67-77.

Wulanndari, Q. D. C. A. (2016). Analisis Kesalahan Menyelesaikan Soal Matematika Materi Matriks pada Siswa Kelas X MAN Trenggalek Tahun Ajaran 2015/2016. Skripsi pada Jurusan Tadris Matematika IAIN Tulungagung: Tidak diterbitkan.

\section{Riwayat Hidup PenUlis \\ Restu Ayu Gustianingrum, S.Pd.}

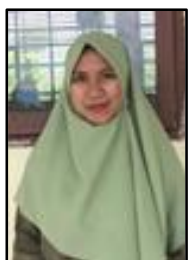

Lahir di Pekanbaru, 9 September 1997. Guru matematika tingkat SMA/MA di Provinsi Riau. Studi S1 Pendidikan Matematika Universitas Riau, lulus tahun 2019; Mahasiswa S2 Pendidikan Matematika FKIP Universitas Riau, Pekanbaru.

\section{Dr. Kartini, M.Si.}

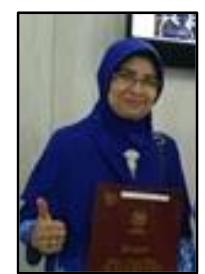

Lahir di Bagan Punak, 3 Juli 1972. Dosen Pascasarjana Pendidikan Matematika FKIP Universitas Riau. Studi S1 Pendidikan Matematika Universitas Riau, lulus tahun 1997; S2 Matematika Institut Teknologi Bandung, lulus tahun 2001; S3 Pendidikan Matematika Universitas Pendidikan Indonesia, lulus tahun 2012. 